\title{
Faktor - Faktor yang Mempengaruhi Kinerja Keuangan Bank Perkreditan Rakyat
}

\author{
I Kadek Sardika Putra ${ }^{1}$ \\ Fakultas Ekonomi dan Bisnis \\ Universitas Udayana, Indonesia
}

\author{
Henny Triyana Hasibuan ${ }^{2}$ \\ Fakultas Ekonomi dan Bisnis \\ Universitas Udayana, Indonesia
}

Surel : jerosardikaputra1102@gmail.com

\section{ABSTRAK}

Penelitian ini bertujuan untuk menguji pengaruh variabel Non Performing Loan (NPL), Loan to Deposit Ratio (LDR) dan Operational Efficiency Ratio (BOPO) terhadap kinerja keuangan BPR yang diproksikan dengan ROA. Populasi dalam penelitian ini adalah seluruh BPR di Kabupaten Badung yang terdaftar di Otoritas Jasa Keuangan (OJK) selama periode 2016-2018. Penentuan sampel menggunakan metode purposive sampling dan diperoleh sebanyak 49 BPR dengan total amatan sebanyak 147. Teknik analisis yang digunakan adalah teknik analisis regresi linier berganda. Hasil penelitian ini menunjukkan bahwa variabel NPL dan LDR tidak berpengaruh terhadap kinerja keuangan, sedangkan $\mathrm{BOPO}$ berpengaruh negatif terhadap kinerja keuangan. Penelitian ini dapat menambah informasi dan pengetahuan mengenai pengaruh NPL, LDR, BOPO terhadap kinerja keuangan BPR yang diproksikan dengan ROA.

Kata Kunci: $\quad$ ROA; NPL; LDR; BOPO.

\section{Factors Affecting the Financial Performance of Rural Banks}

\section{ABSTRACT}

This study aims to examine the effect of the Non Performing Loan (NPL), Loan to Deposit Ratio (LDR) and Operational Efficiency Ratio $(B O P O)$ variables on the financial performance of BPRs as proxied by ROA. The population in this study were all BPRs in Badung Regency which were registered with the Financial Services Authority (OJK) during the 2016-2018 period. Determination of the sample using purposive sampling method and obtained as many as 49 rural banks with a total of 147 observations. The analysis technique used is multiple linear regression analysis techniques. The results of this study indicate that the NPL and LDR variables have no effect on financial performance, while OEOI has a negative effect on financial performance. This research can add information and knowledge about the effect of NPL, LDR, OEOI on BPR financial performance as proxied by ROA.

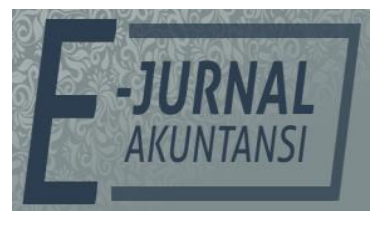

e-ISSN 2302-8556

Vol. 31 No. 9

Denpasar, September 2021 Hal. 2229-2239

DOI:

10.24843/EJA.2021.v31.i09.p06

PENGUTIPAN:

Putra, I.K.S., \& Hasibuan, H.T. (2021). Faktor - Faktor yang Mempengaruhi Kinerja Keuangan Bank Perkreditan Rakyat. E-Jurnal Akuntansi, 31(9), 2229-2239

RIWAYAT ARTIKEL: Artikel Masuk: 6 Januari 2021 Artikel Diterima: 9 September 2021

Keywords: $\quad$ ROA; NPL; LDR; BOPO.

Artikel dapat diakses : https://ojs.unud.ac.id/index.php/Akuntansi/index 


\section{PENDAHULUAN}

Analisis laporan keuangan pada dasarnya bahwa agar laporan keuangan menjadi lebih berarti sehingga dapat dipahami dan dimengerti oleh berbagai pihak, maka perlu dilakukan analisis laporan keuangan. Hasil analisis laporan keuangan juga akan memberikan informasi tentang kelemahan dan kekuatan yang dimiliki perusahaan. Dengan adanya kelemahan dan kekuatan yang dimiliki, akan tergambar kinerja manajemen selama ini (Kasmir, 2016:66).

Profitabilitas yakni rasio yang menilai kemampuan perusahaan dalam mencari keuntungan. Rasio ini dapat juga memberikan ukuran tingkat efektivitas manajemen suatu perusahaan. Hal ini ditunjukkan oleh adanya laba yang dihasilkan dari penjualan dan pendapatan investasi. Inti dari penggunaan rasio ini adalah untuk menunjukkan efisiensi perusahaan (Kasmir, 2016:196).

Rasio profitabilitas dan lebih ke spesifik yaitu Return On Asset (ROA). karena ROA merupakan variabel yang biasa digunakan sebagai alat ukur untuk melihat kinerja keuangan suatu bank. ROA merupakan perbandingan dari laba bersih perusahaan dengan aset yang dimilikinya. Laba merupakan indikator yang dapat digunakan untuk mengukur dan mengevaluasi kinerja perusahaan. Maka semakin besar laba yang dihasilkan perusahaan dalam satu periode akuntansi dapat mengindikasikan kinerja perusahaan semakin baik (Riyadi, 2017:308).

Kinerja keuangan suatu bank juga mencerminkan tingkat kesehatan bank tersebut. Dalam Surat Edaran BI No. 9/24/DPbs disebutkan penilaian tingkat kesehatan bank dipengaruhi oleh faktor CAMELS (Capital, Asset Quality, Management, Earnings, Liquidity, Sensitivity to Market Risk). Aspek Capital meliputi Kewajiban Penyediaan Modal Minimum (KPMM) atau Capital Adequacy Ratio (CAR), aspek Asset Quality meliputi Non Performing Financing (NPF), aspek Earnings meliputi Return On Equity, Return On Asset, dan Operational Efficiency Ratio (BOPO), dan aspek Liquidity meliputi Financing to Deposit Ratio (FDR). Adapun dinamika pergerakan rasio keuangan BPR di Kabupaten Badung per Januari 2016-2018 ditunjukkan dalam Tabel 1, sebagai berikut.

Tabel 1. Data Pergerakan Rasio Keuangan BPR di Kabupaten Badung

\begin{tabular}{llll}
\hline Indikator (\%) & 2016 & 2017 & 2018 \\
\hline ROA & $2,18 \%$ & $1,91 \%$ & $1,69 \%$ \\
NPL & $7,83 \%$ & $9,09 \%$ & $12,17 \%$ \\
LDR & $141,98 \%$ & $122,57 \%$ & $109,23 \%$ \\
BOPO & $71,25 \%$ & $75,48 \%$ & $85,10 \%$ \\
\hline
\end{tabular}

Sumber: Statistik Perbankan BPR pada Bank Indonesia, 2020

Ketetangan:

$\mathrm{ROA} \quad=$ Return on Assets

NPL $\quad=$ Non Performing Loan

LDR = Loan to Deposit Ratio

$\mathrm{BOPO}=$ Biaya Operasional dibagi Pendapatan Operasional

Berdasarkan Tabel 1, ROA dari tahun 2016-2018 mengalami penurunan dari 2,18 persen menjadi 1,69 persen. NPL mengalami kenaikan yaitu dari tahun 20162018 sebesar 7,83 persen menjadi 12,17 persen. Sementara LDR mengalami penurunan yaitu dari tahun 2016-2018 mengalami penurunan dari 141,98 persen menjadi 109,23 persen. BOPO mengalami kenaikan yaitu dari tahun 2016 sebesar 71,25 persen menjadi 85,10 persen pada tahun 2018 . 
Secara umum, kinerja keuangan BPR di Kabupaten Badung dapat dilihat dari rasio ROA per Januari 2016-2018 yang menunjukkan rasio yang tergolong aman bagi bank karena diatas 1,215 persen sesuai yang ditetapkan Bank Indonesia dalam pengkatagorian tingkat kesehatan BPR. Terdapat banyak faktor yang dapat mempengaruhi perubahan ROA bank, seperti faktor internal bank, kondisi makro ekonomi maupun faktor dari nasabah baik faktor kreditur maupun debitur.

Menurut Mahardian (2008) faktor terbesar yang memengaruhi ROA bank adalah tingkat efisiensi operasional yang dilihat dari rasio BOPO bank. Tingginya rasio $\mathrm{BOPO}$ menunjukkan belum optimalnya margin pendapatan operasional bank terhadap biaya operasionalnya yang menunjukkan tidak efisiensinya kegiatan usaha bank. Tidak efisiensinya operasional bank biasanya disebabkan oleh beberapa faktor, seperti tidak mempunyai manajemen dalam mengelola bank akibat rendahnya sumber daya manusia yang dimiliki, rendahnya pemasaran produk, biaya operasional yang terlalu tinggi karena sistem bunga dan lokasi bank yang tidak strategis, yang dimana hal ini bisa dilihat dari data pergerakan rasio keuangan BPR di Kabupaten Badung diatas, yang menunjukkan Rasio BOPO mengalami kenaikan per Januari 2016-2018. Namun jika rasio BOPO bank rendah menunjukkan bahwa bank tersebut mampu mengoptimalkan margin pendapatan operasionalnya atas biaya operasionalnya, sehingga dalam keadaan demikian bank efesien dalam menggunakan sumber daya yang dimiliki baik sumber daya modal maupun sumber daya manusia.

Selain faktor tingkat efisiensi, faktor lain yang dapat mempengaruhi kinerja keuangan bank adalah terjadinya kredit gagal bayar (Non Performing Loan) yang dapat mengurangi pendapatan bank dari sisi kredit. Umumnya sebagian besar kredit yang disalurkan oleh BPR di Kabupaten Badung memiliki kolektibilitas rendah. Hal ini ditunjukkan oleh tingginya rasio NPL bank. Sejak per Januari 20162018, rasio NPL BPR rata-rata diatas rasio yang ditetapkan Bank Indonesia yaitu sebesar 5 persen. Tingginya rasio NPL jelas berdampak terhadap rendahnya tingkat likuiditas bank. Semakin tinggi rasio NPL ini menunjukkan bahwa bank tersebut tidak profesional dalam pengelolaan kreditnya, sekaligus memberikan indikasi bahwa tingkat risiko atas pemberian kredit pada bank tersebut cukup tinggi searah dengan tingginya NPL yang dihadapi bank.

Faktor lain yang dapat memengaruhi kinerja adalah tingkat kecukupan modal dan juga besarnya penyaluran kredit yang dilakukan oleh bank. Adanya modal yang cukup, maka bank akan memiliki peluang besar untuk menggunakannya untuk tujuan produktif, sehingga akan meningkatkan pemenuhan bank. Adanya ekspansi kredit yang dilakukan oleh bank jelas akan meningkatkan profitabilitas bank dari sisi kredit. Jika bank dapat menjaga tingkat kecukupan modal dan tingkat penyaluran kredit tanpa mengesampingkan tingkat likuiditasnya, maka akan meningkatkan kepercayaan masyarakat terhadap bank dan juga kinerja keuangan bank dari sisi pendapatan. Untuk mengukur besarnya penyaluran kredit dan juga tingkat likuiditas umumnya digunakan Loan to Deposit Ratio (LDR). Pada data pergerakan rasio keuangan BPR di Kabupaten Badung diatas, menunjukkan bahwa LDR mengalami penurunan yaitu dari tahun 20162018 mengalami penurunan dari 141,98 persen menjadi 109,23 persen hal ini berarti tingginya kemampuan likuiditas BPR di Bali. Hal ini disebabkan karena jumlah dana yang diperlukan untuk membiayai kredit menjadi semakin kecil. 
Beberapa penelitian terdahulu menunjukkan adanya faktor-faktor yang memengaruhi ROA namun, terjadi ketidak konsistenan dalam penelitian tersebut. NPL yang diteliti oleh Zulfikar (2014) menunjukkan bahwa NPL secara statistik tidak berpengaruh signifikan terhadap ROA. Hal ini berbeda dengan hasil penelitian yang dilakukan Maryadi \& Basuki (2014) NPL tidak berpengaruh negatif dan signifikan terhadap ROA.

Loan to Deposit Ratio (LDR) menunjukkan seberapa besar dana bank dilepaskan ke perkreditan. Semakin tinggi LDR maka laba bank akan semakin meningkat, dengan meningkatnya laba bank maka kinerja bank juga meningkat. Penelitian mengenai LDR yang dilakukan oleh Sasongko (2011) LDR tidak berpengaruh signifikan terhadap ROA. Hal ini berbeda dengan hasil penelitian yang dilakukan oleh Margaretha \& Zai (2013) berpengaruh positif dan signifikan terhadap ROA.

BOPO yang diteliti oleh Zulfikar (2014) menunjukkan bahwa BOPO berpengaruh positif dan signifikan terhadap ROA. Hal ini berbeda dengan hasil penelitian yang dilakukan oleh Margaretha \& Zai (2013) BOPO berpengaruh negatif dan signifikan terhadap ROA.

Non Performing Loan (NPL) adalah rasio yang menunjukkan kemampuan manajemen bank dalam mengatasi kredit bermasalah yang diberikan oleh bank. Kredit yang dimaksud adalah kredit yang diberikan oleh bank kepada pihak ketiga. Bank dalam memberikan kredit harus menganalisis kemampuan pihak ketiga atau debitur tersebut untuk memenuhi kewajibannya. Oleh karena itu apabila bank mempunyai NPL yang tinggi, maka biaya yang dikeluarkan untuk menutup kredit bermasalah juga tinggi, sehingga hal tersebut menurunkan kinerja bank.

Penelitian yang dilakukan oleh Sasongko (2011) menyimpulkan bahwa NPL berpengaruh negatif dan signifikan terhadap ROA. Hal tersebut sejalan dengan penelitian yang dilakukan Aoleh Maryadi \& Basuki (2014) dan Mawardi (2015) yang menyatakan bahwa NPL berpengaruh negatif dan signifikan terhadap ROA. Dari uraian tersebut, maka hipotesis dapat dirumuskan sebagai berikut.

$\mathrm{H}_{1}$ : Non Performing Loan berpengaruh negatif terhadap kinerja keuangan Bank

Perkreditan Rakyat yang diproksikan dengan Return On Asset.

Loan to Deposit Ratio (LDR) merupakan ukuran likuiditas yang mengukur perbandingan dana yang ditempatkan dalam bentuk kredit, yang berasal dari dana pihak ketiga. Kredit yang diberikan tidak termasuk kredit kepada bank lain sedangkan untuk dana pihak ketiga adalah giro, tabungan, simpanan berjangka, dan sertifikat deposito. LDR mencerminkan kemampuan bank dalam memberikan dana yang ditarik oleh nasabah dengan menggunakan kredit yang diberikan sebagai sumber likuiditasnya.

Semakin tinggi nilai rasio LDR menunjukkan bahwa dana yang telah disalurkan lebih tinggi daripada dana pihak ketiga (DPK) yang berada di bank atau tidak tersalurkan kepada pihak yang membutuhkan. Jika rasio LDR bank berada pada standar yang ditetapkan oleh Bank Indonesia, maka laba yang diperoleh oleh bank tersebut akan meningkat (dengan asumsi bank tersebut mampu menyalurkan kreditnya dengan efektif) (Mahardian, 2008). Dengan meningkatnya laba, maka ROA akan meningkat pula. Hal tersebut sejalan dengan penelitian yang telah dilakukan oleh Margaretha \& Zai (2013) dan Kusuma et al. 
(2015) serta Agustiningrum (2013) yang menyatakan bahwa LDR bepengaruh positif terhadap ROA. Dari uraian tersebut, maka hipotesis dapat dirumuskan sebagai berikut.

$\mathrm{H}_{2}$ : Loan to Deposit Ratio berpengaruh positif terhadap kinerja keuangan Bank

Perkreditan Rakyat yang diproksikan dengan Return On Asset.

Operational Efficiency Ratio (BOPO) digunakan dalam mengukur kemampuan pendapatan operasional untuk menutup biaya operasional. Semakin rendah rasio mencerminkan bahwa suatu bank semakin efisien. Karena dengan rendahnya rasio BOPO menunjukkan bahwa bank dapat mengendalikan efisiensi diantara pendapatan operasional dan biaya operasional.

Semakin kecil rasio BOPO mencerminkan semakin efisien pengelolaan bank terhadap biaya operasional. Oleh karena itu jika rasio BOPO semakin kecil maka kinerja bank semakin baik. Penelitian yang dilakukan oleh Maryadi \& Basuki (2014), menyimpulkan bahwa BOPO berpengaruh negatif dan signifikan terhadap kinerja keuangan yang diukur dengan menggunakan ROA. Hal tersebut sejalan dengan penelitian yang dilakukan oleh Nurfahmi \& Rahardjo (2014) dan Kusuma et al. (2015) menyatakan bahwa BOPO berpengaruh negatif dan signifikan terhadap ROA.

Hal ini dapat disimpulkan bahwa tingkat efisiensi bank dalam menjalankan operasi berpengaruh terhadap tingkat laba yang dapat diproksikan dengan ROA. Jika kegiatan operasional dilakukan dengan efisien (dalam hal ini nilai rasio BOPO rendah) maka ROA bank tersebut akan naik. Dari uraian tersebut, maka hipotesis dapat dirumuskan sebagai berikut:

$\mathrm{H}_{3}$ : Operational Effeciency Ratio berpengaruh negatif terhadap kinerja Bank Perkreditan Rakyat yang diproksikan dengan Return On Asset.

\section{METODE PENELITIAN}

Penelitian ini dilakukan pada Bank Perkreditan Rakyat di Kabupaten Badung yang terdaftar di Otoritas Jasa Keuangan (OJK) dengan cara mengakses melalui alamat website www.ojk.go.id. Populasi yang digunakan dalam penelitian ini adalah seluruh Bank Perkreditan Rakyat (BPR) di Kabupaten Badung yang terdaftar di Otoritas Jasa Keuangan (OJK) selama periode 2016-2018 sebanyak 50 BPR. Metode penentuan sampel yang digunakan dalam penelitian ini adalah metode purposive sampling, Berdasarkan data dari OJK, BPR di Kabupaten Badung yang terdaftar di OJK dari tahun 2016 sampai tahun 2018 adalah 50 BPR. BPR tersebut diseleksi kembali menggunakan metode purposive sampling dengan kriteria-kriteria yang telah ditetapkan sebelumnya.

Metode analisis yang digunakan dalam penelitian ini adalah regresi linier berganda dengan menggunakan program aplikasi Statistical Package for Social Science (SPSS). Berdasarkan hipotesis dalam penelitian ini maka metode analisis data yang digunakan adalah analisis kuantitatif untuk memperhitungkan atau memperkirakan secara kuantitatif dari beberapa faktor secara sendiri-sendiri maupun bersama-sama terhadap variabel terikat. Hubungan fungsional antara satu variabel terikat dengan variabel bebas dapat dilakukan dengan regresi linear berganda. Persamaan regresi linier berganda dalam penelitian ini adalah sebagai berikut:

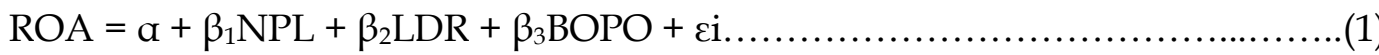




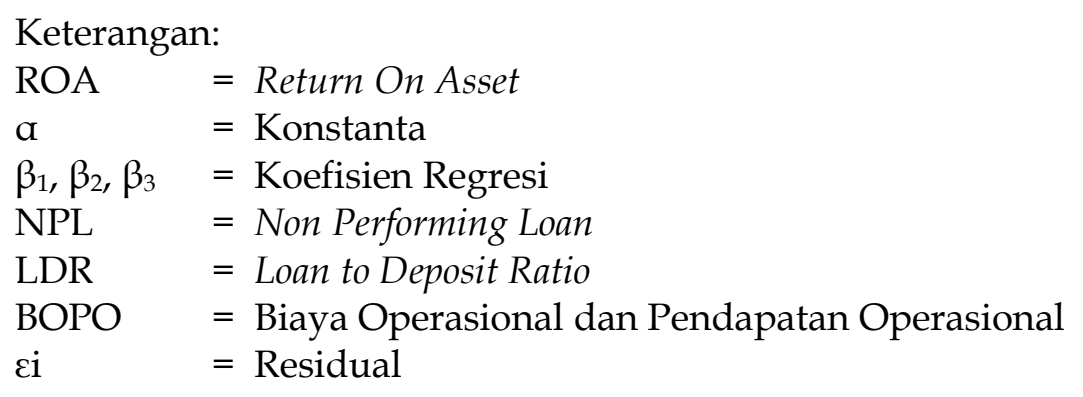

\section{HASIL DAN PEMBAHASAN}

Statistik deskriptif bertujuan untuk memberikan gambaran atau deskripsi tentang variabel-variabel penelitian dari suatu data yang mencangkup jumlah sampel, nilai rata-rata (mean), nilai maksimum, nilai minimum dan standar deviasi dari masing-masing variabel. Berdasarkan pengolahan data SPSS, maka didapatkan hasil analisis dalam Tabel 2, sebagai berikut.

Tabel 2. Hasil Analisis Statistik Deskriptif

\begin{tabular}{lccccc}
\hline & $\mathrm{N}$ & Minimum & Maksimum & Rata-rata & Std. Deviasi \\
\hline NPL & 147 & 0,00 & 0,46 & 0,0989 & 0,08526 \\
LDR & 147 & 0,60 & 2,82 & 1,2713 & 0,42062 \\
BOPO & 147 & 0,27 & 2.01 & 0,7885 & 0,26780 \\
ROA & 147 & $-0,12$ & 0,10 & 0,0176 & 0,02679 \\
Valid N (listwise) & 147 & & & &
\end{tabular}

Sumber: Data Penelitian, 2020

Variabel Non Performing Loan (NPL) memiliki nilai minimum sebesar 0,00 dan nilai maksimum sebesar 0,46 dengan nilai rata-rata 0,0989 dan nilai standar deviasi sebesar 0,08526. Ini berarti bahwa pada BPR dengan sampel tingkat minimum NPL sebesar 0,00 yakni BPR Dalung tahun 2016 dan 2017, BPR Sinar Kita Mulia tahun 2016, BPR Calliste Bestari tahun 2016. Sedangkan sampel tingkat maksimum NPL sebesar 0,46 yakni BPR Gisawa tahun 2018.

Variabel Loan to Deposit Ratio (LDR) memiliki nilai minimum sebesar 0,60 dan nilai maksimum sebesar 2,82 dengan nilai rata-rata 1,2713 dan nilai standar deviasi sebesar 0,42062. Ini berarti bahwa pada BPR dengan sampel tingkat minimum LDR sebesar 0,60 yakni BPR Calliste Bestari tahun 2018. Sedangkan sampel tingkat maksimum LDR sebesar 2,82 yakni BPR Bukit Tanjung tahun 2016.

Variabel Operational Efficiency Ratio (BOPO) memiliki nilai minimum sebesar 0,27 dan nilai maksimum sebesar 2,01 dengan nilai rata-rata 0,7885 dan nilai standar deviasi sebesar 0,26780. Ini berarti bahwa pada BPR dengan sampel tingkat minimum BOPO sebesar 0,27 yakni BPR Jaya Kerti tahun 2017. Sedangkan sampel tingkat maksimum BOPO sebesar 2,01 yakni BPR Adiartha Udiana tahun 2018.

Variabel Kinerja Keuangan di proksikan dengan Return on Asset (ROA) memiliki nilai minimum sebesar -0,12 dan nilai maksimum sebesar 0,10 dengan nilai rata-rata 0,0176 dan nilai standar deviasi sebesar 0,02679. Ini berarti bahwa pada BPR dengan sampel tingkat minimum ROA sebesar -0,12 yakni BPR Calliste Bestari tahun 2018. Sedangkan sampel tingkat maksimum ROA sebesar 0,10 yakni BPR Santi Pala tahun 2018. 
Model regresi linear berganda digunakan untuk mengetahui apakah terdapat pengaruh yang signifikan antara satu variabel terikat dan lebih dari satu variabel bebas. Hasil analisis regresi linier berganda ditunjukkan pada Tabel 3, sebagai berikut.

Tabel 3. Hasil Analisis Regresi Linier Berganda

\begin{tabular}{|c|c|c|c|c|c|}
\hline \multirow[b]{2}{*}{ Model } & \multicolumn{2}{|c|}{$\begin{array}{l}\text { Unstandardized } \\
\text { Coefficients }\end{array}$} & \multirow{2}{*}{$\begin{array}{l}\text { Standardized } \\
\text { Coefficients } \\
\text { Beta }\end{array}$} & \multirow[b]{2}{*}{$\mathrm{t}$} & \multirow[b]{2}{*}{ Sig. } \\
\hline & $\bar{B}$ & Std. Error & & & \\
\hline 1 (Constant) & 0,091 & 0,005 & & 17,928 & 0,000 \\
\hline NPL & 0,019 & 0,013 & 0,060 & 1,398 & 0,164 \\
\hline LDR & $-0,001$ & 0,002 & $-0,013$ & $-0,332$ & 0,741 \\
\hline ВOPO & $-0,094$ & 0,004 & $-0,937$ & $-21,206$ & 0,000 \\
\hline
\end{tabular}

Sumber: Data Penelitian, 2020

Berdasarkan pada Tabel 3, didapatkan hasil persamaan regresi sebagai berikut.

$$
\mathrm{ROA}=0,091+0,019 \mathrm{NPL}-0,001 \mathrm{LDR}-0,094 \mathrm{BOPO}
$$

Nilai konstanta sebesar 0,091. Hal ini berarti jika variabel independen yaitu NPL, LDR dan BOPO tidak ada (sama dengan 0), maka variabel dependen yaitu Kinerja Keuangan yang diproksikan dengan ROA adalah sebesar 0,091.

Nilai koefisien regresi Non Performing Loan (NPL) sebesar 0,019 dengan signifikan 0,164. Hal ini menunjukkan bahwa NPL tidak berpengaruh terhadap Kinerja Keuangan yang diproksikan dengan ROA. Nilai t variabel Non Performing Loan (NPL) adalah positif 1,398 dengan nilai sigifikansi sebesar 0,164 yang lebih besar dari 0,05. Hal ini berarti bahwa NPL tidak berpengaruh terhadap Kinerja Keuangan yang diproksikan dengan ROA. Oleh karena itu hipotesis pertama dinyatakan ditolak. Hasil penelitian menunjukkan bahwa (NPL) tidak berpengaruh terhadap Kinerja Keuangan Bank Perkreditan Rakyat yang diproksikan dengan (ROA), sehingga hipotesis pertama ditolak. Hal ini menunjukkan bahwa kondisi (NPL) yang lebih besar dalam satu periode tidak secara langsung memberikan penurunan laba pada periode yang sama. Ketika bank memiliki jumlah kredit macet yang tinggi maka bank akan berusaha terlebih dahulu mengevaluasi kinerjanya dengan sementara mengurangi penyaluran pembiayaannya hingga (NPL) berkurang. Pertumbuhan kredit merupakan sebuah gambaran tentang tingkat perkembangan volume kredit yang disalurkan kepada pihak ketiga dalam periode tertentu. Semakin optimal penyaluran kredit yang dilakukan oleh masing-masing BPR maka semakin besar pula perolehan labanya.

Berdasarkan hasil penelitian dari Wahyuda et al. (2017) menunjukkan bahwa pertumbuhan kredit ternyata tidak memiliki pengaruh secara signifikan. Hal ini bisa terjadi karena pertumbuhan kredit dimasing-masing BPR tidak sama, ada yang mengalami pertumbuhan yang pesat dan adapula yang mengalami penurunan sehingga tidak berpengaruh terhadap profitabilitas. Selain itu terjadinya NPL atau kredit bermasalah yang tinggi di masing-masing BPR juga menjadi faktor penyebabnya. Angka NPL yang tinggi menunjukkan bahwa pokok pinjaman kredit yang disalurkan tidak mampu untuk dikembalikan oleh nasabah sehingga jumlah kredit atau total kredit yang disalurkan akan tetap kelihatan tinggi namun disisi lain bunga atas pinjaman tersebut juga tidak mampu untuk 
dibayarkan hal ini yang menyebabkan terjadinya penurunan pendapatan bunga atas kredit sehingga profitabilitas atau kinernjanya menurun. Selain itu, suku bunga kredit sangat berperan dalam peningkatan profitabilitas ataupun kinerja BPR. Seperti yang diketahui masyarakat, suku bunga kredit BPR lebih besar dibandingkan dengan Bank Umum, akan tetapi BPR kini sudah mampu menyaingi dengan memberikan produk kredit dengan bunga yang bersaing yang bertujuan untuk mempertahankan nasabahnya. Misalnya dengan ikut menurunkan suku bunga kredit untuk tetap meningkatkan pertumbuhan kreditnya, namun hal ini akan menyebabkan terjadi penurunan pendapatan bunga yang berpengaruh terhadap hasil profitabilitas yang lebih rendah pula. Tidak hanya karena bersaing dengan Bank Umum tapi keadaan ekonomi juga menyebabkan BPR harus menurunkan suku bunga kreditnya agar perekonomian dapat terus berputar. Penelitian ini mendukung penelitian yang dilakukan oleh Wahyuda et al. (2017), Zulfikar (2014) menemukan hasil bahwa NPL tidak berpengaruh terhadap ROA.

Nilai koefisien regresi Loan to Deposit Ratio (LDR) sebesar -0,001 dengan signifikan 0,741. Hal ini menunjukkan bahwa LDR tidak berpengaruh terhadap Kinerja Keuangan yang diproksikan dengan ROA. Nilai t variabel Loan to Deposit Ratio (LDR) adalah negatif 0,332 dengan nilai sigifikansi sebesar 0,741 yang lebih besar dari 0,05. Hal ini berarti bahwa LDR tidak berpengaruh terhadap Kinerja Keuangan yang diproksikan dengan ROA. Oleh karena itu hipotesis kedua dinyatakan ditolak. Hasil penelitian menunjukan bahwa risiko likuiditas tidak berpengaruh terhadap ROA, sehingga hipotesis kedua ditolak. Hasil penelitian menunjukkan bahwa likuiditas (LDR) tidak berpengaruh terhadap kinerja bank (ROA). LDR menunjukkan kemampuan bank dalam menyalurkan kredit dari pihak ketiga kepada para kreditur (masyarakat). Hasil ini tidak sesuai dengan konsep teori likuiditas bahwa semakin banyak dana yang dipinjamkan (likuiditas rendah), semakin tinggi profitabilitas (kinerja bank, ROA). LDR yang tinggi menunjukkan semakin riskan kondisi likuiditas bank, sebaliknya semakin rendah LDR menunjukkan kurang efektifnya bank dalam menyalurkan kredit kepada masyarakat. Efektivitas ini akan berdampak pada efisiensi bank, karena pendapatan operasional bank sebagian besar adalah dari pendapatan bunga kredit atau dana yang dipinjamkan kepada masyarakat.

Hal ini menunjukkan bahwa LDR bukan menjadi penentuan peningkatan jumlah profitabilitas yang diterima oleh bank. LDR tidak berpengaruh terhadap ROA diakibatkan adanya kredit macet sehingga besarnya kredit yang diberikan kurang berdampak pada profiabilitas perbankan. Adanya kredit macet membuat kualitas kredit kurang baik dan menimbulkan peningkatan biaya operasional sehingga kemampuan bank dalam menyalurkan kredit tidak berpengaruh terhadap tingkat pendapatan atau laba bank. Hasil penelitian ini mendukung penelitian yang dilakukan oleh Purwoko \& Sudiyatno (2013) dan Zulfikar (2014), dengan hasil penelitian bahwa LDR tidak berpengaruh terhadap ROA.

Nilai koefisien regesi variabel Operational Efficiency Ratio (BOPO) sebesar 0,094. Hal ini berarti bahwa setiap peningkatan satu satuan variabel BOPO akan menurunkan nilai Kinerja Keuangan yang diproksikan dengan ROA sebesar 0,094 dengan asumsi variabel independen lainnya adalah konstan. Nilai $t$ variabel Operational Efficiency Ratio (BOPO) adalah negatif 21,206 dengan nilai sigifikansi 
sebesar 0,000 yang lebih kecil dari 0,05. Hal ini berarti bahwa BOPO berpengaruh negatif terhadap Kinerja Keuangan yang diproksikan dengan ROA. Oleh karena itu hipotesis ketiga dinyatakan diterima. Kinerja Keuangan Bank Perkreditan Rakyat yang diproksikan dengan ROA, sehingga hipotesis ketiga diterima. Rasio BOPO merupakan rasio yang mengukur efisiensi dan efektivitas operasional suatu perusahaan dengan membandingkan biaya operasional terhadap pendapatan operasional BPR. Hasil penelitian Wahyuda et al. (2017) menunjukkan bahwa semakin rendah tingkat rasio BOPO berarti semakin baik kinerja manajemen BPR tersebut, karena lebih efisien dalam menggunakan sumber daya yang ada atau mampu menekan biaya operasionalnya sehingga profitabilitasnya akan tinggi. Nilai negatif pada koefisien regresi dalam penelitian ini menunjukkan bahwa dengan meningkatnya BOPO menyebabkan profitabilitasnya menurun. Kondisi ini terjadi disebabkan setiap peningkatan biaya operasional tidak diimbangi dengan peningkatan pendapatan operasionalnya sehingga akan mengurangi perolehan laba sebelum pajaknya.

Hasil penelitian ini mendukung penelitian yang dilakukan oleh Maryadi \& Basuki (2014), Margaretha \& Zai (2013), Kusuma et al. (2015), Wahyuda et al. (2017), Hakiim \& Rafsanjani (2016), Eng (2011), Mawardi (2015), Purwoko \& Sudiyatno (2013), Chatarine \& Lestari (2014), Arifuddin (2012), yang menemukan hasil bahwa BOPO memiliki pengaruh negatif terhadap ROA. Penelitian ini menggunakan nilai Adjusted $\mathrm{R}^{2}$ untuka mengukur besarnya koefisien determinasi. Hasil perhitungan koefisien determinasi dapat ditunjukkan pada Tabel 4, berikut ini.

Tabel 4. Hasil Perhitungan Koefisien Determinasi

\begin{tabular}{rrrrrr}
\hline Model & $\mathrm{R}$ & $\mathrm{R}$ Square & Adjusted R Square & $\begin{array}{c}\text { Std. Error of the } \\
\text { Estimate }\end{array}$ & Durbin-Watson \\
\hline 1 & $0,903^{\mathrm{a}}$ & 0,815 & 0,811 & 0,01165 & 2,046 \\
\hline
\end{tabular}

Sumber: Data Penelitian, 2020

Berdasarkan Tabel 4, menunjukkan bahwa nilai koefisien determinasi (Adjusted $R^{2}$ ) sebesar 0,811 atau 81,1 persen yang berarti bahwa sebesar 81,1 persen variasi dari Kinerja Keuangan yang diproksikan dengan ROA (Y) mampu dijelaskan oleh variabel NPL (X1), LDR (X2), dan BOPO (X3), sedangkan sisanya 18,9 persen dipengaruhi oleh variabel lain di luar variabel penelitian. Uji signifikan simultan (uji F) adalah uji yang diginakan untuk mengetahui apakah semua variabel independen dimasukkan dalam model mempunyai pengaruh secara bersama-sama terhadap variabel dependen. Hasil uji signifikan simultan (uji F) dapat ditunjukkan pada Tabel 5, berikut.

Tabel 5. Hasil Uji Signifikan Simultan (Uji F)

\begin{tabular}{|c|c|c|c|c|c|}
\hline Model & $\begin{array}{l}\text { Sum of } \\
\text { Squares }\end{array}$ & Df & Mean Square & $\mathrm{F}$ & Sig. \\
\hline 1 Regression & 0,085 & 3 & 0,028 & 209,942 & $0,000^{b}$ \\
\hline Residual & 0,019 & 143 & 0,000 & & \\
\hline Total & 0,105 & 146 & & & \\
\hline
\end{tabular}

Sumber: Data Penelitian, 2020

Berdasarkan hasil uji F pada Tabel 5, diperoleh nilai F sebesar 209,942 dengan nilai signifikansi sebesar 0,000 yang lebih kecil dari 0,05. Hal ini 
menunjukkan bahwa NPL (X1), LDR (X2), dan BOPO (X3), secara bersama-sama berpengaruh terhadap Kinerja Keuangan yang diproksikan dengan ROA (Y).

\section{SIMPULAN}

Berdasarkan hasil pengujian analisis data dan pembahasan yang telah dilakukan maka dapat ditarik simpulan bahwa Non Performing Loan (NPL) tidak berpengaruh terhadap Kinerja Keuangan Bank Perkreditan Rakyat yang diproksikan dengan Return on Assets (ROA). Hal ini mengindikasikan bahwa meningkatnya kredit bermasalah yang disalurkan oleh bank tidak memberikan pengaruh terhadap tinggi rendahnya kinerja keuangan yang diperoleh oleh bank tersebut. Loan to Deposit Ratio (LDR) tidak berpengaruh terhadap Kinerja Keuangan Bank Perkreditan Rakyat yang diproksikan dengan Return on Assets (ROA). Hal ini mengindikasikan bahwa meningkatnya kredit yang disalurkan oleh bank tidak memberikan pengaruh terhadap tinggi rendahnya tingkat likuiditas yang diperoleh oleh bank tersebut. Operational Efficiency Ratio (BOPO) berpengaruh negatif terhadap Kinerja Keuangan Bank Perkreditan Rakyat yang diproksikan dengan Return on Assets (ROA). Hal ini mengindikasikan bahwa meningkatnya biaya operasional yang terdapat pada bank akan mengakibatkan turunnya profitabilitas atau kinerja yang akan dihasilkan oleh bank.

Disarankan kepada peneliti selanjutnya untuk meneliti variabel-variabel lain diluar penelitian ini, seperti variabel Capital Adequacy Ratio (CAR), Net Interest Marginal (NIM) dan Debt to Equity Ratio (DER) serta diharapkan mampu menambahkan referensi terhadap variabel-variabel yang diteliti.

\section{REFERENSI}

Agustiningrum, R. (2013). Analisis Pengaruh CAR, NPL, dan LDR Terhadap Profitabilitas Pada Perusahaan Perbankan. E-Jurnal Manajemen Universitas Udayana.

Arifuddin, A. (2012). Analisis Pengaruh CAR, LDR, BOPO, dan NPL terhadap ROA $B P R$ dan Perbandingan ROA antar BPR wilayah Sulawesi Selatan dengan BPR wilayah Iramasuka (Periode 2008-2010). Universitas Hasanuddin Makassar.

Chatarine, A., \& Lestari, P. (2014). Pengaruh Kualitas Aktiva Produktif, Bopo Terhadap ROA DAN CAR Pada BPR Kabupaten Badung. E-Jurnal Manajemen Universitas Udayana.

Eng, S. T. (2011). Pengaruh NIM, BOPO, LDR, NPL dan CAR Terhadap ROA. Bank Internasional Go Public Periode 2007-2011. Jurnal Dinamika Manajemen, 1(3).

Hakiim, N., \& Rafsanjani, H. (2016). Pengaruh Internal Capital Adequency Ratio (CAR), Financing To Deposit Ratio (FDR), dan Biaya Operasional Per Pendapatan Operasional (BOPO) dalam Peningkatan Profitabilitas Industri Bank Syariah di Indonesia. Jurnal Aplikasi Manajemen. https://doi.org/https://doi.org/10.18202/jam23026332.14.1.17

Kasmir. (2016). Analisis Laporan Keuangan. PT Raja Grafindo Persada.

Kusuma, D. P., Mulyadi, \& Abdurakhman. (2015). Analisis Pengaruh CAR, NPL, LDR dan NIM Terhadap Profitabilitas Perbankan (Studi Kasus Pada Bank Umum yang Tercatat Pada BEI Tahun 2008-2012). JAFFA, 3(1).

Mahardian, P. (2008). Analisis Pengaruh Rasio CAR, BOPO, NPL, NIM dan LDR Terhadap Kinerja Keuangan Perbankan (Studi Kasus Perusahaan Perbankan 
Yang Tercatat Di BEJ Periode Juni 2002-Juni 2007). Journal University Of Diponegoro.

Margaretha, F., \& Zai, M. P. (2013). Faktor-Faktor Yang Mempengaruhi Kinerja Keuangan Perbankan Indonesia. Jurnal Bisnis Dan Akuntansi.

Maryadi, S., \& Basuki, A. T. (2014). Determinan Kinerja Keuangan Bank Perkreditan Rakyat Konvensional [Determinants of Financial Performance of Conventional Rural Banks]. Jurnal Ekonomi Dan Studi Pembangunan.

Mawardi, W. (2015). Analisis Faktor-Faktor Yang Mempengaruhi Kinerja Keuangan Bank Umum Di Indonesia. Jurnal Bisnis Strategi.

Nurfahmi, H. A., \& Rahardjo, S. N. (2014). Analisis Pengaruh Rasio Keuanganterhadap Kinerja Bank (Studi pada Perbankan yang Terdaftar di BEI Tahun 2010-2012). Diponegoro Journal Of Accounting, 3(4), 1-11.

OJK. (2020). Data Pergerakan Rasio Keuangan BPR di Kabupaten Badung. Www.Ojk.Go.Id.

Purwoko, D., \& Sudiyatno, B. (2013). Faktor-Faktor Yang Mempengaruhi Kinerja Bank (Studi Empirik Pada Industri Perbankan Di Bursa Efek Indonesia). Journal of Business Economics and Management.

Riyadi, S. (2017). Management Perbankan Indonesia: Teori, Praktek dan Studi Kasus. Raja Grafindo Persada.

Sasongko, D. S. (2011). Pengaruh CAR, BOPO, NIM, NPL dan LDR terhadap Kinerja Perusahaan Perbankan. Sebelas Maret.

Wahyuda, K. D. P., Herawati, N. T., \& Atmadja, A. T. (2017). Pengaruh Pertumbuhan Dana Pihak Ketiga, Pertumbuhan Kredit dan BOPO terhadap Profitabilitas BPR di Bali Periode 2013-2015. Jurnal S1 Akuntansi, 8(2).

Zulfikar, T. (2014). Pengaruh CAR, LDR, NPL, BOPO dan NIM Terhadap Kinerja Profitabilitas (ROA) Bank Perkreditan Rakyat Di Indonesia. E-Journal Graduate Unpar. 